\title{
Donor Polymorphisms in Genes Related to B-Cell Biology Associated With Antibody-Mediated Rejection After Heart Transplantation
}

\author{
Grecia M. Marrón-Liñares, BSc; Lucía Núñez, PhD; María G. Crespo-Leiro, MD, PhD; \\ Eloy Álvarez-López, BSc; Eduardo Barge-Caballero, MD, PhD; \\ Gonzalo Barge-Caballero, MD; David Couto-Mallón, MD; Concepción Pradas-Irun, MD; \\ Javier Muñiz, MD, PhD; Carmela Tan, MD; E. Rene Rodríguez, MD; \\ José Manuel Vázquez-Rodríguez, MD, PhD; Manuel Hermida-Prieto, BSc, PhD
}

\begin{abstract}
Background: Heart transplantation (HT) is a well-established lifesaving treatment for endstage cardiac failure. Antibody-mediated rejection (AMR) represents one of the main problems after HT because of its diagnostic complexity and the poor evidence for supporting treatments. Complement cascade and B-cells play a key role in AMR and contribute to graft damage. This study explored the importance of variants in genes related to complement pathway and B-cell biology in HT and AMR in donors and in donorrecipient pairs.
\end{abstract}

Methods and Results: Genetic variants in 112 genes (51 complement and 61 B-cell biology genes) were analyzed on next-generation sequencing in 28 donor-recipient pairs, 14 recipients with and 14 recipients without AMR. Statistical analysis was performed with SNPStats, R, and EPIDAT3.1. We identified one single nucleotide polymorphism (SNP) in donors in genes related to B-cell biology, interleukin-4 receptor subunit a (p.Ile75Val-IL4Ra), which correlated with the development of AMR. Moreover, in the analysis of recipient-donor genotype discrepancies, we identified another SNP, in this case in adenosine deaminase $(A D A ; p . V a l 178(p=))$, which was related to B-cell biology, associated with the absence of AMR.

Conclusions: Donor polymorphisms and recipient-donor discrepancies in genes related to the biology of B-cells, could have an important role in the development of AMR. In contrast, no variants in donor or in donor-recipient pairs in complement pathways seem to have an impact on AMR.

Key Words: Antibody-mediated rejection; B-cell gene; Donor genotype; Heart transplantation

$\mathbf{H}$ eart transplantation (HT) is a well-established lifesaving treatment for endstage cardiac failure. ${ }^{1}$ Antibody-mediated rejection (AMR), however, represents one of the main problems for clinical management of HT because of its diagnostic complexity and poor evidence for supporting treatment. ${ }^{2}$

The molecular mechanism involved in AMR is still unknown, but an important role of the complement cascade and $\mathrm{B}$ cells has been established., ${ }^{2,3}$ On the one hand, complement activation triggers a strong inflammatory response, and also generates tissue-bound and soluble fragments related to AMR. ${ }^{4}$ And on the other hand, B cells play an important role in the immune response by producing antibodies, presenting antigens to $\mathrm{T}$ cells, and secreting cytokines., ${ }^{\mathbf{5}}$ In both pathways, there are more than 120 genes encoding proteins (isotypes and subunits; Figure 1) involved in complement activation, immunoglobulin gene rearrangement, maturation, activation and differentiation of B cells. ${ }^{7,8}$

There have been many attempts to associate solid organ allograft outcomes with specific genetic variants, ${ }^{9}$ but most studies have focused on recipient genotypes. Our group recently found that polymorphisms in recipients in complement ${ }^{10}$ and in B-cell pathways (Núñez et al, unpublished

Received December 3, 2017; revised manuscript received January 24, 2018; accepted January 29, 2018; released online April 3, 2018 Time for primary review: 36 days

Cardiovascular Research Group (G.M.M.-L., L.N., E.A.-L., J.M., M.H.-P.), Cardiology Service (M.G.C.-L., E.B.-C., G.B.-C., D.C.-M., J.M.V.-R.), Cardiac Surgery Service (C.P.-I.), Institute of Biomedical Research of A Coruña (INIBIC), A Coruña University Hospital Complex (CHUAC), Galician Healthcare Service (Sergas), University of Coruña, Coruña, Spain; Department of Pathology, Cleveland Clinic, Cleveland, OH (C.T., E.R.R.), USA

The first two authors contributed equally to this work (G.M.M.-L., L.N.).

Mailing address: Manuel Hermida-Prieto, BSc, PhD, Instituto de Investigación Biomédica de la Universidad de A Coruña (INIBIC). Complexo Hospitalario Universitario de A Coruña (CHUAC)-Universidad de A Coruña, As Xubias de Arriba 84, A Coruña, 15006, Spain. E-mail: manuelhermidaprieto@gmail.com

ISSN-1346-9843 All rights are reserved to the Japanese Circulation Society. For permissions, please e-mail: cj@j-circ.or.jp 


\section{Complement Pathway}

Alternative Pathway

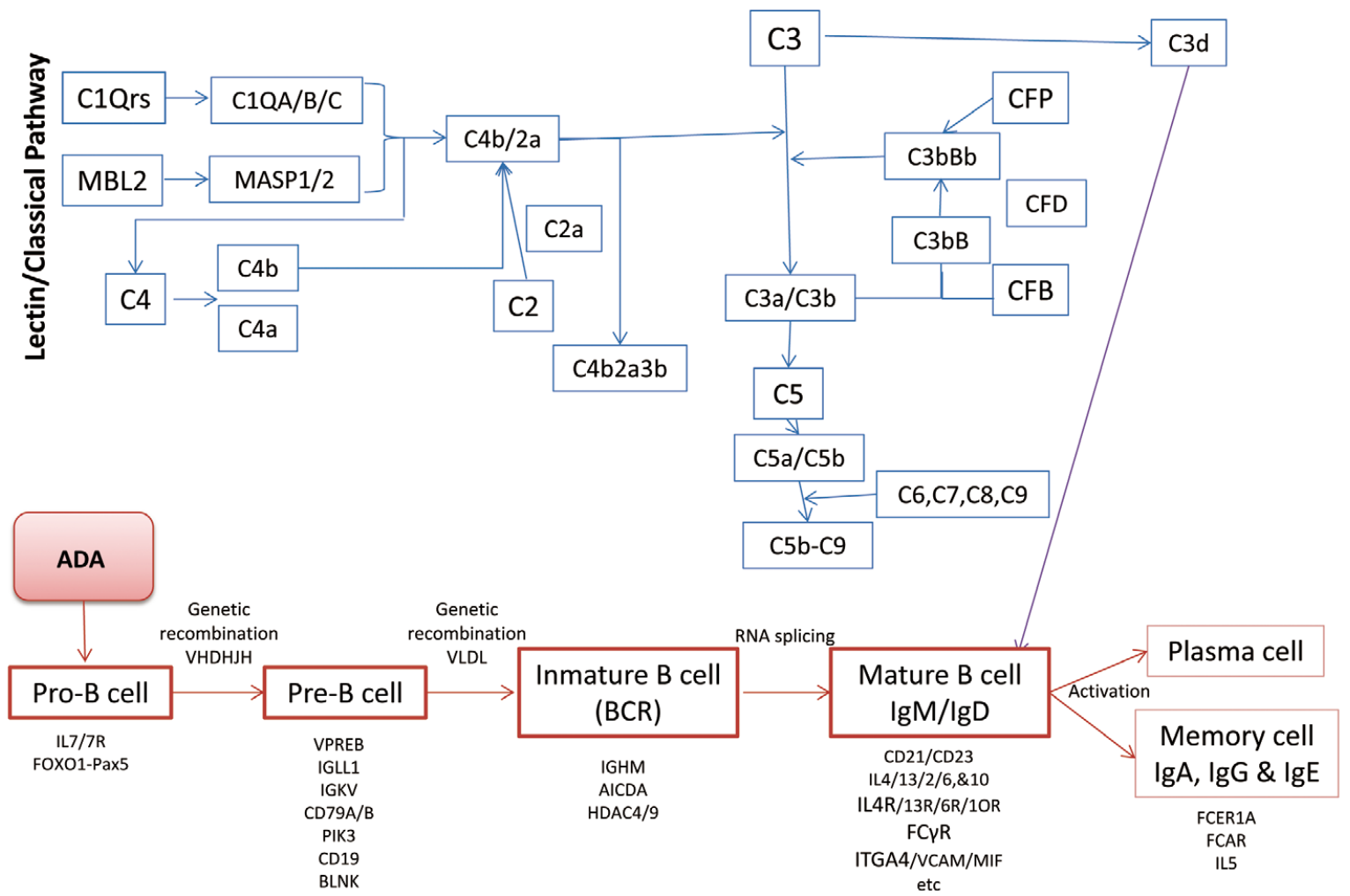

Figure 1. Complement pathway and B-cell development and activation. Summary of the main genes implicated in both pathways. ADA, adenosine deaminase.

data, 2018) are associated with AMR. In recent years there has been increasing interest in donor genotype associated with allograft outcome. ${ }^{11-15}$ With regard to complement and B-cell pathways, there are, at least, 22 studies (Table 1) on the association between donor or donor-recipient pair genotype and different solid organ transplant outcomes. ${ }^{14,16-36}$ Sixteen of the 22 studies noted an association between single nucleotide polymorphism (SNP) and transplant outcome, indicating the importance of genetics in this field. Most of the studies, however, analyzed the association between one or two genes and different outcomes, in which the complement and B-cell role is not always clear. Surprisingly, despite the importance of complement pathway or B-cell biology in AMR, there have been no studies on the association between donor variants in these pathways and AMR. Moreover, it is important to note that none of the complement studies was performed in the field of HT, and only five studies related to B-cell biology were conducted in the field of HT. ${ }^{27,29,31-33}$ Given these findings, the aim of this study was therefore to examine the importance of the genes related to complement pathway and B-cell biology in HT and AMR in donors and in donor-recipient pairs.

\section{Methods}

\section{Patients}

A total of 14 patients with and 14 patients without AMR (controls) after HT and their corresponding donors were selected for the study (total subjects, $n=56$ ). The diagnostic criteria for AMR differed according to whether the transplant date was before or after 2013. AMR in patients with transplantation before $2013(n=7)$ was defined according to the following criteria: (1) allograft dysfunction (left ventricular ejection fraction $[\mathrm{LVEF}],<30 \%$ and/or heart failure); (2) no evidence of other causes of allograft dysfunction (acute cellular rejection or cardiac allograft vasculopathy); (3) evidence of complement activation on endomyocardial biopsy (EMB; C4d and/or C3d staining); and/or (4) favorable response to therapy addressing AMR (including plasmapheresis, rituximab, steroids boluses, i.v. immunoglobulin etc.). AMR in patients with transplantation after $2013(n=7)$ was classified according to International Society for Heart and Lung Transplantation (ISHLT) categories, ${ }^{37,38}$ and the inclusion criterion was at least 1 positive EMB (pAMR1 or higher). Controls did not have any distinguishing signs of AMR (pAMR0), or allograft dysfunction. All samples were from the "Colección de Muestras Para la Investigación de Insuficiencia Cardiaca Avanzada y Trasplante Cardiaco" registered in the Institute of Health Carlos III (C_0000419, 2012/348). The study was performed in accordance with the Declaration of Helsinki and was approved by the ethics committee of "Investigación de Galicia" (ref: 2014/012). 
Table 1. Previous Studies on Donor or Recipient-Donor Gene Variants Associated With Allograft Outcome

\begin{tabular}{|c|c|c|c|c|c|c|}
\hline COMPLEMENT & $\begin{array}{l}\text { Organ } \\
\text { transplanted } \\
\text { PATHWAY }\end{array}$ & $D$ and $R$ & $\begin{array}{l}\text { Gene studied } \\
\text { (polymorphism) }\end{array}$ & No. patients & Outcome & Findings \\
\hline $\begin{array}{l}\text { Brown et al } \\
(2006)^{26}\end{array}$ & Kidney & D-R pairs & C3 (rs2230199) & 501 & Graft outcome & No association \\
\hline $\begin{array}{l}\text { Varagunam } \\
\text { et al }(2009)^{25}\end{array}$ & Kidney & D-R pairs & C3 (rs2230199) & 1,147 & Graft outcome & $\begin{array}{l}\text { D-R discrepancies } \\
\rightarrow \text { worst prognosis }\end{array}$ \\
\hline $\begin{array}{l}\text { Cervera et al } \\
(2009)^{14}\end{array}$ & Liver & $\mathrm{D}$ & $\begin{array}{l}\text { MBL2 (promoter and } \\
\text { rs5030737, rs1800450, } \\
\text { and rs1800451) }\end{array}$ & 95 & $\begin{array}{l}\text { Infections, } A R \text {, } \\
\text { and graft survival }\end{array}$ & $\begin{array}{l}\text { D with rs } 5030737 \text {, } \\
\text { rs } 1800450 \text {, and rs } 180045 \\
\rightarrow \text { worst prognosis }\end{array}$ \\
\hline $\begin{array}{l}\text { Dhillon et al } \\
(2010)^{24}\end{array}$ & Liver & D-R pairs & C3 (rs2230199) & 296 & Graft outcome & No association \\
\hline $\begin{array}{l}\text { Jeong et al } \\
(2011)^{22}\end{array}$ & Kidney & D-R pairs & $\begin{array}{l}\text { C5 (rs2159776, rs17611, } \\
\text { rs25681 and rs2241004 } \\
\text { (GGCG haplotype)) and } \\
\text { C5aR (rs10404456) }\end{array}$ & 191 & Graft outcome & $\begin{array}{l}\downarrow \text { Renal function in } \\
\text { GGCG in R and D. No } \\
\text { association in C5aR }\end{array}$ \\
\hline $\begin{array}{l}\text { Wahrmann } \\
\text { et al }(2011)^{23}\end{array}$ & Kidney & D-R pairs & C4 (CNVs) & 1,969 & Graft survival & No association \\
\hline $\begin{array}{l}\text { Bazyar et al } \\
(2012)^{20}\end{array}$ & Kidney & D-R pairs & C3 (rs2230199) & 100 & AR & No association \\
\hline $\begin{array}{l}\text { Damman } \\
\text { et al }(2012)^{21}\end{array}$ & Kidney & D-R pairs & C3 (rs2230199) & 1,265 & $\begin{array}{l}\text { PNF, AR, DGF, PS } \\
\text { and graft outcome }\end{array}$ & $\begin{array}{l}\text { D polymorphism } \\
\text { associated with PNF }\end{array}$ \\
\hline $\begin{array}{l}\text { Budding et al } \\
(2016)^{17}\end{array}$ & Lung & D & CD59 (promoter) & 137 & Graft survival & $\begin{array}{l}\text { D polymorphism: } \\
\text { impaired long-term } \\
\text { survival and } \uparrow \text { incidence } \\
\text { of BOS }\end{array}$ \\
\hline $\begin{array}{l}\text { Ermini et al } \\
(2016)^{16}\end{array}$ & Kidney & D-R pairs & $\begin{array}{l}47 \text { genes (505 tagged } \\
\text { SNP) }\end{array}$ & $\begin{array}{l}\text { Two cohorts of } 650 \\
\text { and } 520 \text { patients }\end{array}$ & Graft outcome & No association \\
\hline \multicolumn{7}{|c|}{ B-CELL BIOLOGY } \\
\hline $\begin{array}{l}\text { Sankaran } \\
\text { et al }(1999)^{36}\end{array}$ & Kidney & $\mathrm{D}$ and $\mathrm{R}$ & $\begin{array}{l}\text { TNFa (promoter) and } \\
\text { IL10 (promoter) }\end{array}$ & 115 & RES and RS & $\begin{array}{l}\mathrm{R} T N F a \text { and } I L 10 \\
\text { polymorphisms are } \\
\text { determinant in RES } \\
\text { and RS }\end{array}$ \\
\hline $\begin{array}{l}\text { Awad et al } \\
(2001)^{32}\end{array}$ & $\begin{array}{l}\text { Pediatric } \\
\text { heart }\end{array}$ & $\mathrm{D}$ and $\mathrm{R}$ & $\begin{array}{l}\text { TNFa (promoter), IL10 } \\
\text { (promoter), IL6 (promoter), } \\
\text { TGF } 1 \text { (rs1800470 and } \\
\text { rs1800471) and IFNY } \\
\text { (rs2430561) }\end{array}$ & $93 \mathrm{R}$ and $29 \mathrm{D}$ & AR & $\begin{array}{l}\text { R polymorphisms } \\
\text { associated with AR }\end{array}$ \\
\hline $\begin{array}{l}\text { Holweg et al } \\
(2001)^{33}\end{array}$ & Heart & $\mathrm{D}$ and $\mathrm{R}$ & $\begin{array}{l}\text { TGF } \beta 1 \text { (rs1800470 and } \\
\text { rs } 1800471)\end{array}$ & $252 R$ and $213 D$ & $\begin{array}{l}\text { Chronic allograft } \\
\text { failure }\end{array}$ & $\begin{array}{l}\text { R polymorphisms } \\
\text { associated with chronic } \\
\text { allograft failure }\end{array}$ \\
\hline $\begin{array}{l}\text { Poole et al } \\
(2001)^{34}\end{array}$ & Kidney & D-R pairs & $\begin{array}{l}\text { IL10 (promoter), and } \\
\text { IL4 (promoter) }\end{array}$ & 120 & $\begin{array}{l}\text { AR and graft } \\
\text { outcome }\end{array}$ & $\begin{array}{l}\text { D and R IL4 and IL10 } \\
\text { genotypes influence } \\
\text { renal transplantation } \\
\text { outcome and AR }\end{array}$ \\
\hline $\begin{array}{l}\text { Marshall } \\
\text { et al }(2001)^{35}\end{array}$ & Kidney & $\begin{array}{l}\mathrm{D} \text { and } \mathrm{R} \text { and } \\
\mathrm{D}-\mathrm{R} \text { pairs }\end{array}$ & IL6 (promoter) & $\begin{array}{c}145 \mathrm{D}, 209 \mathrm{R} \text { and } \\
126 \text { pairs }\end{array}$ & $\mathrm{AR}$ & $\begin{array}{l}\text { D IL6 genotype } \rightarrow \text { major } \\
\text { genetic risk of } A R\end{array}$ \\
\hline $\begin{array}{l}\text { Bijlsma et al } \\
(2002)^{31}\end{array}$ & Heart & $\mathrm{D}$ and $\mathrm{R}$ & IL4 (Promoter) & 167 & AR & D genotype $\downarrow$ AR \\
\hline $\begin{array}{l}\text { Densem } \\
\text { et al }(2004)^{29}\end{array}$ & Heart & $\mathrm{D}$ and $\mathrm{R}$ & $\begin{array}{l}\text { TGFB1 (rs18041006 } \\
\text { and rs1982073) }\end{array}$ & $147 R$ and $134 \mathrm{D}$ & $\mathrm{CV}$ & R rs18041006 $\uparrow \mathrm{CV}$ \\
\hline $\begin{array}{l}\text { Hoffmann } \\
\text { et al }(2004)^{30}\end{array}$ & Kidney & $\mathrm{D}$ & $\begin{array}{l}\text { IL2, IL6, IL10, TNFa, } \\
\text { TGFB, IFNY, CCR2, } \\
\text { CCR5 (polymorphism } \\
\text { related with AR) }\end{array}$ & 68 & AR & $\begin{array}{l}\text { D polymorphisms } \\
\rightarrow \text { influence } R \text { immune } \\
\text { response }\end{array}$ \\
\hline $\begin{array}{l}\text { Karabon } \\
\text { et al }(2005)^{28}\end{array}$ & $\begin{array}{l}\text { Hematopoietic } \\
\text { stem cell }\end{array}$ & $\mathrm{D}$ and $\mathrm{R}$ & IL6 and IL10 (promoter) & $93 \mathrm{R}$ and $74 \mathrm{D}$ & aGVHD & $\begin{array}{l}\text { D polymorphism } I L 10 \\
\text { and } I L 6 \rightarrow \text { effect in the } \\
\text { risk of aGVHD }\end{array}$ \\
\hline $\begin{array}{l}\text { Fildes et al } \\
(2005)^{27}\end{array}$ & Heart & $\mathrm{D}$ and $\mathrm{R}$ & $\begin{array}{l}\text { CCR5 (rs333 } \\
(\text { CCR5 } 32))\end{array}$ & 178 & Graft outcome & D genotype $\rightarrow$ mortality \\
\hline $\begin{array}{l}\text { Biggins et al } \\
(2013)^{18}\end{array}$ & Liver & $\begin{array}{l}R \text { and } D-R \\
\text { pairs }\end{array}$ & $\begin{array}{l}\text { IL28B (rs12979860 and } \\
\text { rs8099917) DDX58 } \\
\text { (rs10813831) }\end{array}$ & $\begin{array}{l}440 R \text { and } 225 \\
D-R \text { pairs }\end{array}$ & $\begin{array}{l}\text { Severity of HCV } \\
\text { recurrence }\end{array}$ & $\begin{array}{l}\text { D genotype } \uparrow \text { Risk } \\
\text { HCV }\end{array}$ \\
\hline $\begin{array}{l}\text { Firpi et al } \\
(2013)^{19}\end{array}$ & Liver & D-R pairs & IL28B (rs12979860) & 135 & HCV outcome & $\begin{array}{l}\mathrm{D} \text { and } \mathrm{R} \text { genotype } \\
\rightarrow \text { better response to } \\
\text { treatment }\end{array}$ \\
\hline
\end{tabular}

aGVHD, acute graft-vs.-host disease; AR, acute rejection; BOS, bronchiolitis obliterans syndrome; CV, coronary vasculopathy; D, donor; DGF, delayed graft function; HCV, hepatitis $\mathrm{C}$ virus; PNF, primary non-function; PS, patient survival; R, recipient; RES, steroid-resistant or responsive; RS, rejection severity. 


\begin{tabular}{|c|c|c|c|c|}
\hline \multirow[b]{2}{*}{ Variable } & \multicolumn{2}{|c|}{ AMR } & \multicolumn{2}{|c|}{ Non-AMR } \\
\hline & $\begin{array}{c}\text { Recipients } \\
(n=14)\end{array}$ & $\begin{array}{c}\text { Donors } \\
(n=14)\end{array}$ & $\begin{array}{c}\text { Recipients } \\
(n=14)\end{array}$ & $\begin{array}{l}\text { Donors } \\
(n=14)\end{array}$ \\
\hline Age (years) & $45.7 \pm 4.9$ & $46.5 \pm 3.2$ & $45.3 \pm 4.7$ & $36.3 \pm 2.9$ \\
\hline Male & $78.6(11)$ & $64.3(9)$ & $78.6(11)$ & $71.4(10)$ \\
\hline Female & $21.4(3)$ & $35.7(5)$ & $21.4(3)$ & $28.6(4)$ \\
\hline \multicolumn{5}{|l|}{ Primary heart disease } \\
\hline Dilated cardiomyopathy & $21.4(3)$ & & $28.6(4)$ & \\
\hline Ischemic cardiomyopathy & $42.9(6)$ & & $35.7(5)$ & \\
\hline Valvular cardiomyopathy & $7.1(1)$ & & $7.1(1)$ & \\
\hline Others & $28.6(4)$ & & $28.6(4)$ & \\
\hline \multicolumn{5}{|l|}{ Time since transplant (years) } \\
\hline$<2$ & $28.6(4)$ & & $7.1(1)$ & \\
\hline $2-5$ & $28.6(4)$ & & $14.3(2)$ & \\
\hline$\geq 6$ & $42.9(6)$ & & $78.6(11)$ & \\
\hline Time to AMR diagnosis after transplant (years) & $2.4 \pm 0.6$ & & & \\
\hline \multicolumn{5}{|l|}{ CMV serology status } \\
\hline $\mathrm{D}+/ \mathrm{R}+$ & $64.3(9)$ & & $64.3(9)$ & \\
\hline $\mathrm{D}-/ \mathrm{R}-$ & 0 & & 0 & \\
\hline $\mathrm{D}+/ \mathrm{R}-$ & $21.4(3)$ & & $28.6(4)$ & \\
\hline $\mathrm{D}-/ \mathrm{R}+$ & $14.3(2)$ & & $7.1(1)$ & \\
\hline \multicolumn{5}{|l|}{ Inmunosupression } \\
\hline Cyclosporine & $57.1(8)$ & & $28.6(4)$ & \\
\hline Plasmapheresis & $51.1(8)$ & & 0 & \\
\hline Steroids & $100(14)$ & & $100(14)$ & \\
\hline Mycophenolate mofetil & $85.7(12)$ & & $92.9(13)$ & \\
\hline Tacrolimus & $78.6(11)$ & & $50.0(7)$ & \\
\hline Everolimus & $35.7(5)$ & & $42.9(6)$ & \\
\hline Basiliximab & $92.6(13)$ & & $92.6(13)$ & \\
\hline Daclizumab & 0 & & $7.1(1)$ & \\
\hline Rituximab & $51.1(8)$ & & 0 & \\
\hline Thymoglobulin & $7.1(1)$ & & 0 & \\
\hline
\end{tabular}

Data given as mean \pm SD or \% (n). AMR, antibody-mediated rejection; CMV, cytomegalovirus; D, donor; R, recipient.

\section{Targeted Next-Generation Sequencing Genetic Analysis}

Genomic DNA from the patients with and without AMR and their corresponding donors $(\mathrm{n}=56)$ was extracted from clots and blood samples using QIAamp DNA Blood Mini Kit (Qiagen, Hilden, Germany) as previously described. ${ }^{10}$ All samples were included in the next-generation sequencing (NGS) study using the TruSight One panel according to manufacturer instructions (Illumina, San Diego, CA, USA). The TruSight One is a commercial NGS panel for the targeted genomic enrichment of 4,813 genes including 51 genes related to the complement pathway and 61 genes related to the biology of B cells (Table S1). The samples were paired-end sequenced on a NextSeq500 platform (Illumina) and mapped to the human genome reference sequence (GRCh37, hg19).

\section{Databases and In Silico Tools}

The potential effect of SNP associated with the presence of AMR was predicted using in silico tools as previously described. ${ }^{10}$ Moreover, the minor allele frequency (MAF) of the SNP described was checked on two different databases: Single Nucleotide Polymorphism Database (dbSNP) and/or Exome Aggregation Consortium (ExAC).

Variant Localization Topological placement of the mutations was done using the Swissprot database (http://ca. expasy.org/uniprot/). The Uniprot database provides generally accepted residue ranges corresponding to each domain region and specialized subregion.

Prediction of Damaging Amino Acid Substitution Five online tools were used to predict the pathogenicity of the missense variants: SIFT (http://sift.jcvi.org/www/SIFT_seq_ submit2.html), Polyphen-2 (http://genetics.bwh.harvard. edu/pph2/), PhDSNP (http://snps.biofold.org/phd-snp/ phd-snp.html), SNAP2 (https://www.rostlab.org/services/ snap/), and MutationTaster (http://www.mutationtaster. org).

Prediction of Exonic Splicing Enhancer Variants The effect of synonymous variants in the splice-enhancing sequences was evaluated using HSF (http://www.umd.be/HSF/).

\section{Quality of NGS Sequencing}

The mean coverage of all the genes related to the complement pathway or the biology of B cells was as high as $83.7 \pm 2.5$-fold. Direct sequencing of 24 different amplicons (Table S1), containing at least one variant on NGS each, was performed to evaluate sensitivity $[\mathrm{TP} /(\mathrm{TP}+\mathrm{FN})]$, specificity $[\mathrm{TN} /(\mathrm{TN}+\mathrm{FP})]$, and accuracy $[(\mathrm{TP}+\mathrm{TN}) /(\mathrm{TP}+$ $\mathrm{FP}+\mathrm{FN}+\mathrm{TN})]$ of the NGS technique, where TP means true positive, TN means true negative, FP means false positive, and FN means false negative. After analyzing all 


\begin{tabular}{|c|c|c|c|c|c|c|c|}
\hline $\begin{array}{c}\text { rs1805010 IL4R p.lle75Val / } \\
\text { Model }\end{array}$ & Genotype & $\begin{array}{l}\text { Non-AMR } \\
n(\%)\end{array}$ & $\begin{array}{l}\text { AMR } \\
\text { n (\%) }\end{array}$ & OR $(95 \% \mathrm{Cl})$ & P-value & AIC & BIC \\
\hline \multicolumn{8}{|l|}{ SNPstats } \\
\hline \multirow[t]{3}{*}{ Codominant } & $\mathrm{A} / \mathrm{A}$ & $10(71.4)$ & $2(15.4)$ & 1.00 & \multirow{3}{*}{0.0073} & \multirow{3}{*}{33.6} & \multirow{3}{*}{37.5} \\
\hline & $\mathrm{A} / \mathrm{G}$ & $4(28.6)$ & $10(76.9)$ & $12.50(1.85-84.44)$ & & & \\
\hline & $\mathrm{G} / \mathrm{G}$ & $0(0)$ & $1(7.7)$ & NA $(0.00-N A)$ & & & \\
\hline \multirow[t]{2}{*}{ Dominant } & $\mathrm{A} / \mathrm{A}$ & $10(71.4)$ & $2(15.4)$ & 1.00 & \multirow{2}{*}{0.0024} & \multirow{2}{*}{32.2} & \multirow{2}{*}{34.8} \\
\hline & $\mathrm{A} / \mathrm{G}-\mathrm{G} / \mathrm{G}$ & $4(28.6)$ & $11(84.6)$ & $13.75(2.05-92.04)$ & & & \\
\hline \multirow[t]{2}{*}{ Recessive } & $\mathrm{A} / \mathrm{A}-\mathrm{A} / \mathrm{G}$ & $14(100)$ & 12 (92.3) & 1.00 & \multirow{2}{*}{0.22} & \multirow{2}{*}{39.9} & \multirow{2}{*}{42.5} \\
\hline & $\mathrm{G} / \mathrm{G}$ & $0(0)$ & $1(7.7)$ & NA $(0.00-N A)$ & & & \\
\hline \multirow[t]{2}{*}{ Overdominant } & $\mathrm{A} / \mathrm{A}-\mathrm{G} / \mathrm{G}$ & $10(71.4)$ & $3(23.1)$ & 1.00 & \multirow{2}{*}{0.01} & \multirow{2}{*}{34.8} & \multirow{2}{*}{37.4} \\
\hline & $\mathrm{A} / \mathrm{G}$ & $4(28.6)$ & $10(76.9)$ & $8.33(1.47-47.23)$ & & & \\
\hline Log-additive & - & - & - & $12.99(1.99-84.58)$ & 0.0018 & 31.6 & 34.2 \\
\hline \multicolumn{8}{|l|}{$R(F(x)$ association) } \\
\hline \multirow[t]{3}{*}{ Codominant } & $\mathrm{A} / \mathrm{A}$ & $10(71.4)$ & $2(15.4)$ & 1.00 & \multirow{3}{*}{0.0063} & \multirow{3}{*}{33.6} & \\
\hline & $A / G$ & $4(28.6)$ & $10(76.9)$ & $12.50(1.85-84.44)$ & & & \\
\hline & $\mathrm{G} / \mathrm{G}$ & $0(0)$ & $1(7.7)$ & 0.00 & & & \\
\hline \multirow[t]{2}{*}{ Dominant } & $\mathrm{A} / \mathrm{A}$ & $10(71.4)$ & $2(15.4)$ & 1.00 & \multirow{2}{*}{0.0024} & \multirow{2}{*}{32.2} & \\
\hline & A/G-G/G & $4(28.6)$ & $11(84.6)$ & $13.75(2.05-92.04)$ & & & \\
\hline \multirow[t]{2}{*}{ Recessive } & $\mathrm{A} / \mathrm{A}-\mathrm{A} / \mathrm{G}$ & $14(100)$ & $12(92.3)$ & 1.00 & \multirow{2}{*}{0.4815} & \multirow{2}{*}{39.9} & \\
\hline & $\mathrm{G} / \mathrm{G}$ & $0(0)$ & $1(7.7)$ & 0.00 & & & \\
\hline \multirow[t]{2}{*}{ Overdominant } & $\mathrm{A} / \mathrm{A}-\mathrm{G} / \mathrm{G}$ & $10(71.4)$ & $3(23.1)$ & 1.00 & \multirow{2}{*}{0.0102} & \multirow{2}{*}{34.8} & \\
\hline & $\mathrm{A} / \mathrm{G}$ & $4(28.6)$ & $10(76.9)$ & $8.33(1.47-47.23)$ & & & \\
\hline Log-additive & - & - & - & $12.99(1.99-84.58)$ & 0.0063 & 31.6 & \\
\hline $\begin{array}{l}\text { Fisher's exact test (omnibus } \\
\text { P-value) }\end{array}$ & & & & & 0.0213 & & \\
\hline
\end{tabular}

AIC, Akaike information criterion; AMR, antibody-mediated rejection; BIC, Bayes information criterion; IL4R, interleukin 4 receptor.

the genes included in the study we obtained a sensitivity of $94.5 \%$, a specificity of $100 \%$, and an accuracy of $99.9 \%$.

\section{Statistical Analysis}

For the association of donor genotype in genes related to complement and B-cell biology, multiple inheritance models (codominant, dominant, recessive, overdominant, and logadditive) were applied using SNPStats and the R association function. When these models showed a significant association, Fisher's exact test in $\mathrm{R}$ was used. The strength of association between SNP and AMR was estimated using OR, 95\% CI, Akaike information criterion (AIC), Bayes information criterion (BIC) and P-value, using both SNPStats and R. Moreover, to identify recipient-donor pair genotype in genes related to the complement pathway and B-cell biology potentially associated with the risk of humoral rejection, Fisher's exact test in EPIDAT 3.1 was used. Due to the exploratory nature of these analyses, $\mathrm{P} \leq 0.02$ was required in order to limit the risk of spurious associations.

\section{Results}

\section{Baseline Clinical Characteristics}

Baseline donor and recipients characteristics are listed in Table 2. In both groups of recipients, the most common transplant etiology was cardiomyopathy $(71.4 \%)$. Using the pathologic AMR classification in patients after 2013 $(n=7)$, based on a scale consisting of immunopathology and histological features, ${ }^{36,37} 4$ patients were classified as pAMR(I+) and 3 patients as pAMR2. Tables 2,S2 list cytomegalovirus (CMV) serology status, immunosuppression regimen and AMR treatment.

\section{Donor Genotype and AMR}

Complement Genes A total of 51 genes related to the complement were analyzed in 28 donors (14 to patients with AMR and 14 to patients without AMR; Table S1). On sequencing of all codifying and adjacent regions, from position -10 to +10 , of the selected genes from the $28 \mathrm{HT}$ donors, 257 SNP were identified (Table S3). After statistical analysis, none of the donor SNP in the complement pathway was associated with AMR.

Genes Related to B-Cell Biology A total of 61 genes related to B-cell biology were screened in 28 donors to 14 AMR patients and to 14 controls (Table S1). A total of 222 SNP were identified in the analyzed genes (Table S3), and one of these variants was significantly associated with AMR (codominant, $\mathrm{P}=0.01$; dominant, $\mathrm{P}=0.002$; overdominant, $\mathrm{P}=0.01$; log-additive, $\mathrm{P}=0.002$; Table 3 ). This polymorphism in interleukin-4 receptor subunit $\alpha(I L-4 R \alpha)$, an adenine to guanine substitution on the c. 223 nucleotide that produces the substitution of the 75 lysine for valine (rs1805010; p.Ile75Val; Figure 2), was present more often in AMR donors than in control donors. We used in silico software to predict the effect on the function of the protein, and it was predicted to be tolerated by all the bioinformatics tools used (SIFT=tolerated (1), POLYPHEN=benign (0.001), $\mathrm{PhDSNP}=$ neutral, Mutation Taster=polymorphism $(1,0)$, $\mathrm{SNAP}=$ neutral $(87 \%)$, with the score of each in silico tool given in parentheses). 


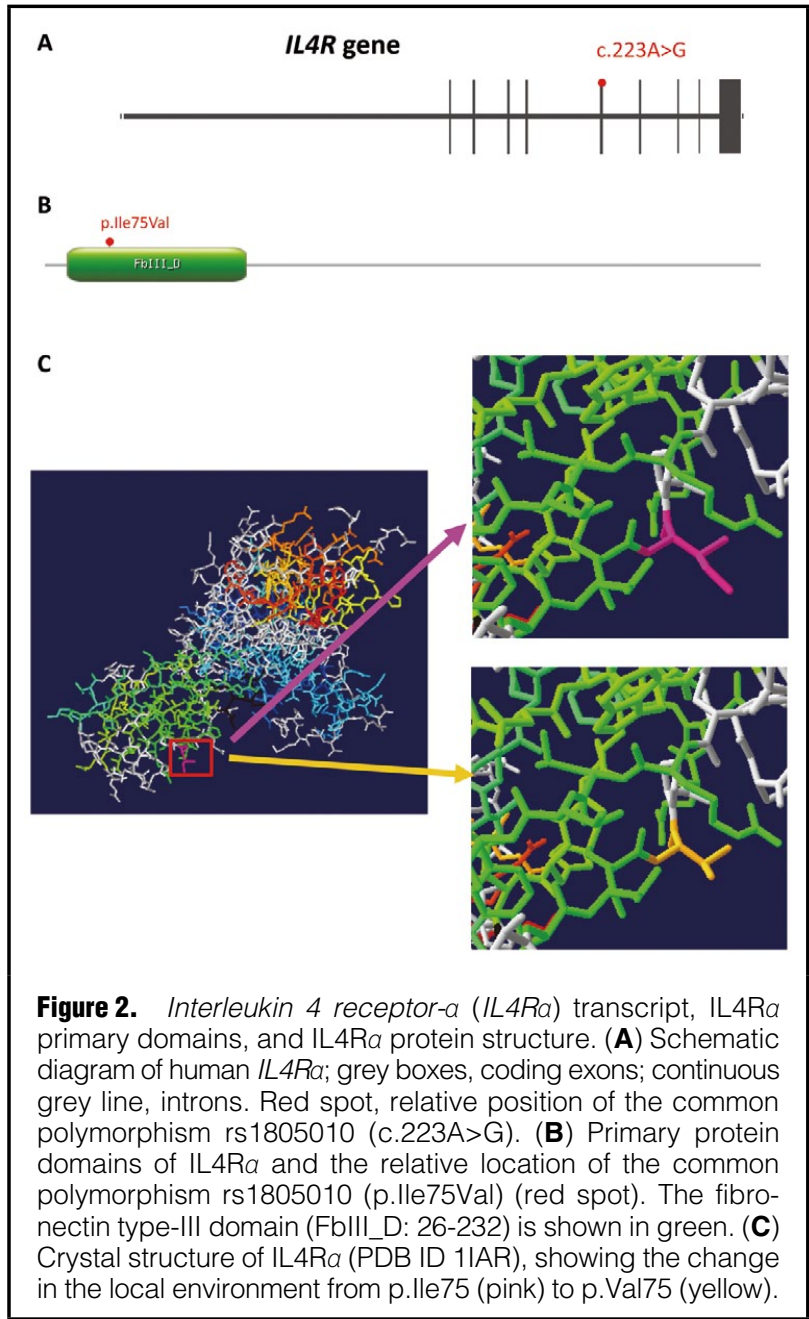

\section{Recipient-Donor Genotype and AMR}

The genotype of the most relevant genes in the complement pathway and in the biology of B cells was analyzed in 14 donor-recipient pairs in which the recipients developed AMR $(n=28)$, and in 14 pairs in which the recipients did not $(n=28)$. After the analysis of 112 genes, 662 SNP were identified (Table S3). The first analysis compared the total number of donor-recipient discrepancies in the 662 SNP between the AMR group and the control group. The mean number of discrepancies in the AMR group was 103.6 \pm 3.3 whereas in the control group it was 108.7 $\pm 8.4(\mathrm{P}=\mathrm{NS})$.

The second analysis compared the frequency of each SNP in the donor-recipient pairs between the AMR and non-AMR groups. For this purpose, SNP with minor allele frequency $<7 \%$, meaning the presence of the alternative allele in $<5$ patients out of 56, were left out of further analysis ( $\mathrm{n}=402$, Table S3). Thus, we compared the distribution of genotype frequency in $260 \mathrm{SNP}$ in donors and recipients as follows: (1) $\mathrm{D}+/ \mathrm{R}+$; (2) $\mathrm{D}+/ \mathrm{R}-$; (3) $\mathrm{D}-/ \mathrm{R}+$; and (4) D-/R- in AMR and control group, where+means the presence of the variant while-means the reference nucleotide. After this analysis, only one SNP found in adenosine deaminase (ADA; p.Val178( $\mathrm{p}=)$, rs244076; Figure 3A), related to B-cell biology, had a statistically significant distribution (Table 4, $\mathrm{P}<0.02$ ). Moreover, the presence of this allele had an inverse association with the appearance of AMR $(\mathrm{D}-/ \mathrm{R}-\mathrm{vs}$. $\mathrm{D}+/ \mathrm{R}+$ or $\mathrm{D}+/ \mathrm{R}-$ or $\mathrm{D}-/ \mathrm{R}+$ ), with an OR of 0.07 (95\% CI: $0.01-0.44, \mathrm{P}=0.006$ ). This variant could modify the exonic splicing enhancer (Table 5), and thus, it could have an impact on protein expression.

\section{Discussion}

This study is the first analysis of the effect of donor and recipient-donor pair variants, in genes involved in the complement pathway and B-cell biology, related to AMR in HT patients. We identified $1 \mathrm{SNP}$, p.Ile75Val in interleukin 4 receptor- $\alpha$ (IL4R $\alpha$; rs1805010), in donors that correlated with the development of AMR. Moreover, in the analysis of recipient-donor discrepancies, we identified 1 SNP, p.Val178 $(\mathrm{p}=)$ in $A D A(\mathrm{rs} 244076)$ related with B-cell biology,

\section{ADA gene}

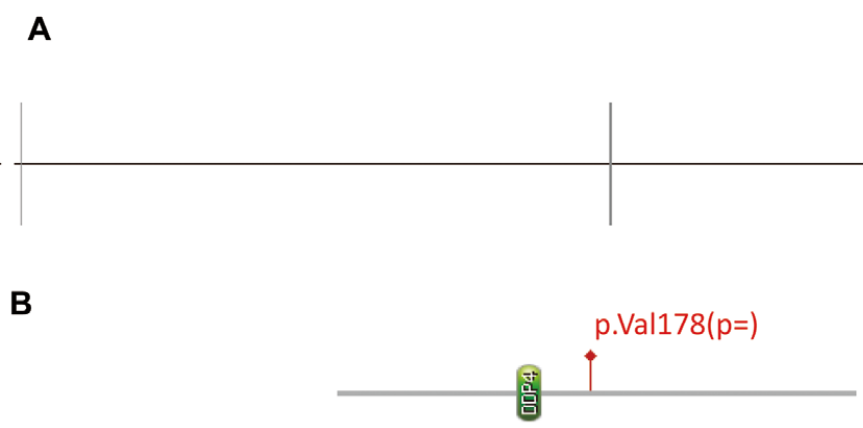

Figure 3. Adenosine deaminase $(A D A)$ transcript and primary domains. (A) Schematic diagram of human $A D A$ and $(\mathbf{B})$ primary protein domains of ADA showing the relative position of the common polymorphism rs244076 (c.534A>G, $p . V a l 178(p=)$ ). Red spot, polymorphism position. 
associated with the absence of AMR. No SNP, however, in complement pathway genes, either in donor or in recipientdonor pairs, was associated with AMR. Thus, the present data are in concordance with several studies that noted the importance of donor genotype in allograft outcome. 14,19-20,31 In fact, Biggins et al had noted that $I L 28 B$ and $D D X 58$ SNP that are favourable when present in the recipient, are unfavorable when present in the donor graft. ${ }^{18}$

\section{Donor Variant p.Ile75Val in IL4Ra: Association With AMR}

In recent years, the number of studies focused, not only on recipient, but also on donor genotype in genes related to complement and B-cell biology that could have an effect on transplant outcome, have increased (Table 1). Twelve out of 22 studies reviewed noted an influence of donor genotype in five different types of transplantation (kidney, $\mathrm{n}=5$; liver, $\mathrm{n}=3$; heart, $\mathrm{n}=2$; lung, $\mathrm{n}=1$; and hematopoietic stem cell, $n=1$ ) with different endpoints studied (acute rejection, $n=7$; graft survival and outcome, $n=6$; infection, $\mathrm{n}=3){ }^{14,17-19,21,22,27,28,30,31,34,35}$ The genes associated with transplantation outcomes were interleukins (IL4, IL6,IL10, and $I L 28 B),{ }^{18,19,28,30,31,34,39}$ different proteins of the complement cascade $(C 3, C 5, C D 59$, and $M B L 2),{ }^{14,17,21,22}$ and two genes related to the activation of $\mathrm{B}$ cells (CCR5 and DDX58). ${ }^{\mathbf{1 8 , 2 7}}$

Surprisingly, despite the importance of the complement cascade and B-cell biology in AMR, no studies have been carried out on the genes in these two pathways in HT with AMR. In this sense, in the present patients, no SNP in the complement cascade genes was associated with AMR. But, although no SNP in the IL genes was associated with AMR, the presence of the variant p.Ile75Val in $I L 4 R \alpha$, which codes for the interleukin-4 receptor subunit $\alpha$, in donors, was associated with AMR.

IL-4R $\alpha$ mediated signaling on B cells drives the production of type 2 antibody isotypes $\mathrm{IgG} 1$ and $\mathrm{IgE}$ through STAT6 in response to IL4 stimulation. ${ }^{40}$ The extracellular variant p.Ile $75 \mathrm{Val}$, or p.Ile50Val relative to the mature peptide, in $I L 4 R \alpha$ identified in the present cohort and associated with AMR has been described in several studies on asthma, type 1 diabetes, hyper-IgE syndrome, and severe eczema.41-43 The p.Ile75Val polymorphism, named rs180510 on dbSNP, has been described as a gain-offunction mutation due to a sustained STAT6 phosphorylation. ${ }^{44}$ This variant was associated with an increase in total serum $\operatorname{IgE}$ in atopic asthma, related to its active role in isotype class-switch recombination. ${ }^{42}$ Thus, to identify a

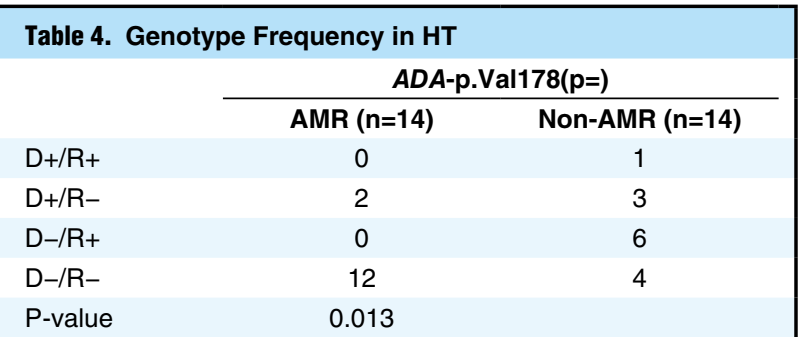

AMR, antibody-mediated rejection; D, donor; $\mathrm{HT}$, heart transplantation; $R$, recipient

possible role of $I L 4 R \alpha$ p.Ile75Val in AMR, we can speculate, based on all these studies, that donors with the allele Val75, associated with gain of function, would present more $\operatorname{IgE} / \operatorname{IgG}$ due to sustained STAT6 phosphorylation. This modification would in turn increase IL4 stimulation, thereby skewing towards the T-helper cell 2 response by increasing B-cell activity. ${ }^{45}$ Moreover, the major production of $\mathrm{IgG}$ by $\mathrm{B}$ cells could increase the activation of the complement pathway, which could increase the risk of AMR. ${ }^{46}$ More research is needed, however, to analyze this hypothesis and the role of donor p.Ile75Val variant in AMR.

\section{Recipient-Donor Genotype Discrepancy and AMR}

Despite the fact that several studies have noted that recipient-donor genotype discrepancy in genes related to complement activation and B-cell biology could affect transplant outcome, the results were inconclusive because of the low number of genes analyzed and the different outcomes studied (Table 1). The present study analyzed 112 genes, in a more ambitious strategy, and we focused on AMR due to the importance of complement cascade and B-cells in this entity. We did not find any SNP in complement genes related to AMR either in donor or in donorrecipient pairs, in concordance with previous studies that failed to find an association with acute rejection ${ }^{20}$ or with graft outcomes. ${ }^{\mathbf{1 6 , 2 3 , 2 4 , 2 6}}$ Thus, complement genes related to AMR seem to be important in recipients, and not in donors, as we have previously noted.10

In contrast, all of the studies carried out in genes related to B-cell biology in transplantation noted a relationship with various outcomes: acute rejection; ${ }^{28,30-32,34-36}$ graft

\begin{tabular}{|c|c|c|c|c|c|}
\hline \multicolumn{6}{|c|}{ ESE finder matrices for SRp40, SC35, SF2/ASF and SRp55 } \\
\hline \multirow[t]{2}{*}{ Variant } & \multicolumn{2}{|c|}{ Reference motif } & \multicolumn{2}{|c|}{ Mutant motif } & \multirow[t]{2}{*}{ Variation } \\
\hline & Linked SR protein & $\begin{array}{l}\text { Reference motif } \\
\text { (value 0-100) }\end{array}$ & Linked SR protein & $\begin{array}{l}\text { Reference motif } \\
\text { (value 0-100) }\end{array}$ & \\
\hline p.Val178 $(\mathrm{p}=) A D A$ & SC35 & AGCCATTG (75.8) & SC35 & GGCCATTG (86.5) & $+14.2 \%$ \\
\hline \multicolumn{6}{|c|}{ ESE motifs from HSF } \\
\hline \multirow[t]{3}{*}{ Variant } & \multicolumn{2}{|c|}{ Reference motif } & \multicolumn{2}{|c|}{ Mutant motif } & Variation \\
\hline & Reference motif & Motif value (0-100) & Mutant motif & Motif value $(0-100)$ & \\
\hline & & Reference sequence & & Mutant sequence & \\
\hline \multirow[t]{2}{*}{ p.Val178 $(\mathrm{p}=) A D A$} & & & $9 \mathrm{G} 8$ & GGTGGC (66.9) & New site \\
\hline & $9 \mathrm{G} 8$ & GTAGCC (63.4) & & & $\begin{array}{c}\text { Site broken } \\
-100 \mathrm{~A}\end{array}$ \\
\hline
\end{tabular}

DA, adenosine deaminase; ESE, exonic splicing enhancer; HSF, human splicing finder. 
outcome; ${ }^{27,29,33,34}$ and infection. ${ }^{18,19}$ In the present study, after analyzing more than 316 SNP in 61 genes, we found an association between recipient-donor discrepanct in only 1 synonymous SNP, p.Val178( $\mathrm{p}=)$, in $A D A$ related to B-cell biology. Due to the more frequent presence of the alternative allele in the donor-recipient pair in the control group, this polymorphism could have a protective effect against AMR. Although it is a synonymous variant, silent SNP can alter the final protein conformation. ${ }^{47,48}$ In the present study, on in silico analysis, $\mathrm{p}$. Val178 $(\mathrm{p}=)$ could modify the exonic splicing enhancer and possibly have an impact on protein expression. More research is needed, however, to verify this hypothesis.

Most of the studies conducted in B-cell genes in different organ transplantation found an association with IL genes or tumor necrosis factor- $\alpha$ (Table 1). Thus, this is the first description of a variant in $A D A$ related to a transplantation outcome: AMR. ADA is a ubiquitously expressed metabolic enzyme that plays an integral role in numerous cellular processes and is encoded by $A D A{ }^{49} \mathrm{ADA}$ is well known due to a severe combined immunodeficiency (ADA-SCID) in which there is dysfunction of both B and $\mathrm{T}$ lymphocytes with decreased production of $\mathrm{Ig}$, resulting from mutations in the gene encoding ADA. ${ }^{49}$ Moreover, polymorphisms in $A D A$ also have been related to other pathologies such as autism, asthma, and rheumatoid arthritis. ${ }^{47,50,51}$ In the Sharma et al study, a significant association was found between the present identified variant, p.Vall78 $(\mathrm{p}=)$, and a poor response to rheumatoid arthritis. ${ }^{47}$ Unfortunately they did not describe any mechanism by which the variant could affect the response.

\section{Study Limitations}

The main limitations of the present study were (1) the relatively small sample size because of the unicentric study design, the low incidence of AMR and the availability of donor samples; and (2) the modification over time in the routine diagnosis of AMR on EMB, which in the present center was not included in the routine protocol until 2013. The donor SNP and also the recipient-donor discrepancies in B-cell genes associated with AMR identified in the present study, could introduce a new approach into the treatment of AMR and could open up a new field of study.

\section{Conclusions}

Donor polymorphisms as well as recipient-donor discrepancies in B-cell biology genes, could have an important role in the development of AMR. No variants in donor or in donor-recipient pairs in the complement pathways, however, seems to have an impact in AMR.

\section{Acknowledgments}

We thank Zulaika Grille-Cancela, Paula Blanco-Canosa, Drs. Natalia Suarez-Fuentetaja, and Nieves Domenech-García for their assistance with samples and database records. We also thank Dr. Maria J Paniagua-Martin for clinical follow-up and Jorge Pombo-Otero for the pathology classification.

\section{Funding}

This work was supported by a grant from Instituto de Salud Carlos III (PI13/02174) and is part of the research activities of the Centro de investigación Biomédica en Red Enfermedades Cardiovasculares (CIBERCV). Co-financed with FEDER Funds.

\section{Disclosures}

The authors declare no conflict of interest.

\section{References}

1. Tible M, Loupy A, Vernerey D, Suberbielle C, Beuscart T, Cazes A, et al. Pathologic classification of antibodymediated rejection correlates with donorspecific antibodies and endothelial cell activation. J Heart Lung Transplant 2013; 32: 769-776.

2. Colvin MM, Cook JL, Chang P, Francis G, Hsu DT, Kiernan MS, et al. Antibody-mediated rejection in cardiac transplantation: Emerging knowledge in diagnosis and management: A scientific statement from the American Heart Association. Circulation 2015; 131: $1608-1639$.

3. Banham GD, Clatworthy MR. B-cell biomarkers in transplantation: From genes to therapy. Tissue Antigens 2015; 85: 82-92.

4. Stites E, Le Quintrec M, Thurman JM. The complement system and antibody-mediated transplant rejection. J Immunol 2015; 195: $5525-5531$.

5. Wortel CM, Heidt S. Regulatory B cells: Phenotype, function and role in transplantation. Transpl Immunol 2017; 41: 1-9.

6. Suzuki J, Isobe M, Morishita R, Nagai R. Characteristics of chronic rejection in heart transplantation: Important elements of pathogenesis and future treatments. Circ J 2010; 74: 233-239.

7. Mayilyan KR. Complement genetics, deficiencies, and disease associations. Protein Cell 2012; 3: 487-496.

8. Pieper K, Grimbacher B, Eible H. B-cell biology and development. J Allergy Clin Immunol 2013; 131: 959-971.

9. Oetting WS, Guan W, Schladt DP, Leduc RE, Jacobson PA, Matas AJ, et al. Donor polymorphisms of toll-like receptor 4 associated with graft failure in liver transplant recipients. Liver Transpl 2012; 18: 1399-1405.

10. Marrón-Liñares GM, Núñez L, Crespo-Leiro MG, BargeCaballero E, Pombo J, Paniagua-Martin MJ, et al. Polymorphisms in genes related to the complement system and antibody mediated cardiac allograft rejection. J Heart Lung Transplant 2018; 37: 477-485.

11. Dessing MC, Kers J, Damman J, Navis GJ, Florquin S, Leemans JC. Donor and recipient genetic variants in NLRP3 associate with early acute rejection following kidney transplantation. Sci Rep 2016; 6: 36315 .

12. Mandegary A, Rahmanian-Koshkaki S, Mohammadifar MA, Pourgholi L, Mehdipour M, Etminan A, et al. Investigation of association between donors' and recipients' NADPH oxidase p22(phox) C242T polymorphism and acute rejection, delayed graft function and blood pressure in renal allograft recipients. Transpl Immunol 2015; 32: 46-50.

13. Hauser IA, Kruck S, Gauer S, Nies AT, Winter S, Bedke J, et al. Human pregnane $\mathrm{X}$ receptor genotype of the donor but not of the recipient is a risk factor for delayed graft function after renal transplantation. Clin Pharmacol Ther 2012; 91: 905-916.

14. Cervera C, Balderramo D, Suárez B, Prieto J, Fuster F, Linares $\mathrm{L}$, et al. Donor mannose-binding lectin gene polymorphisms influence the outcome of liver transplantation. Liver Transpl 2009; 15: 1217-1224.

15. Buis CI, van der Steege G, Visser DS, Nolte IM, Hepkema BG, Nijsten M, et al. Heme oxygenase-1 genotype of the donor is associated with graft survival after liver transplantation. Am $J$ Transplant 2008; 8: 377-385.

16. Ermini L, Weale ME, Brown KM, Mesa IR, Howell WM, Vaughan R, et al. Systematic assessment of the influence of complement gene polymorphisms on kidney transplant outcome. Immunobiology 2016; 221: 528-534.

17. Budding K, van de Graaf EA, Kardol-Hoefnagel T, Broen JC, Kwakkel-van Erp JM, Oudijk EJ, et al. A promoter polymorphism in the CD59 complement regulatory protein gene in donor lungs correlates with a higher risk for chronic rejection after lung transplantation. Am J Transplant 2016; 16: 987-998.

18. Biggins SW, Trotter J, Gralla J, Burton JR Jr, Bambha KM, Dodge J, et al. Differential effects of donor and recipient IL28B and DDX58 SNPs on severity of HCV after liver transplantation. J Hepatol 2013; 58: 969-976.

19. Firpi RJ, Dong H, Clark VC, Soldevila-Pico C, Morelli G, Cabrera R, et al. CC genotype donors for the interleukin-28B single nucleotide polymorphism are associated with better outcomes in hepatitis C after liver transplant. Liver Int 2013; 33: $72-78$.

20. Bazyar N, Azarpira N, Khatami SR, Galehdari H, Salahi H. Complement $\mathrm{C} 3$ gene polymorphism in renal transplantation (an 
Iranian experience). Gene 2012; 498: 254-258.

21. Damman J, Daha MR, Leuvenink HG, van Goor H, Hillebrands JL, Dijk MC, et al. Association of complement C3 gene variants with renal transplant outcome of deceased cardiac dead donor kidneys. Am J Transplant 2012; 12: 660-668.

22. Jeong JC, Hwang YH, Kim H, Ro H, Park HC, Kim YJ, et al. Association of complement 5 genetic polymorphism with renal allograft outcomes in Korea. Nephrol Dial Transplant 2011; 26: $3378-3385$.

23. Wahrmann M, Döhler B, Ruhenstroth A, Haslacher H, Perkmann T, Exner M, et al. Genotypic diversity of complement component $\mathrm{C} 4$ does not predict kidney transplant outcome. $J$ Am Soc Nephrol 2011; 22: 367-376.

24. Dhillon N, Walsh L, Krüger B, Mehrotra A, Ward SC, Godbold $\mathrm{J}$, et al. Complement component $\mathrm{C} 3$ allotypes and outcomes in liver transplantation. Liver Transpl 2010; 16: 198-203.

25. Varagunam M, Yaqoob MM, Döhler B, Opelz G. C3 polymorphisms and allograft outcome in renal transplantation. $N$ Engl $J$ Med 2009; 360: 874-880.

26. Brown KM, Kondeatis E, Vaughan RW, Kon SP, Farmer CK, Taylor JD, et al. Influence of donor C3 allotype on late renaltransplantation outcome. N Engl J Med 2006; 354: 2014-2023.

27. Fildes JE, Walker AH, Howlett R, Bittar MN, Hutchinson IV, Leonard CT, et al. Donor CCR5 Delta32 polymorphism and outcome following cardiac transplantation. Transplant Proc 2005; 37: 2247-2249.

28. Karabon L, Wysoczanska B, Bogunia-Kubik K, Suchnicki K, Lange A. IL-6 and IL-10 promoter gene polymorphisms of patients and donors of allogeneic sibling hematopoietic stem cell transplants associate with the risk of acute graft-versus-host disease. Hum Immunol 2005; 66: 700-710.

29. Densem CG, Hutchinson IV, Yonan N, Brooks NH. Donor and recipient-transforming growth factor-beta 1 polymorphism and cardiac transplant-related coronary artery disease. Transpl Immunol 2004; 13: 211-217.

30. Hoffmann S, Park J, Jacobson LM, Muehrer RJ, Lorentzen D, Kleiner D, et al. Donor genomics influence graft events: The effect of donor polymorphisms on acute rejection and chronic allograft nephropathy. Kidney Int 2004; 66: 1686-1693.

31. Bijlsma FJ, van Kuik J, van Hoffen E, de Jonge N, Tilanus MG, Gmelig-Meyling FH, et al. Acute cardiac transplant rejection is associated with low frequencies of interleukin-4 producing helper T-lymphocytes rather than with interleukin-4 promoter or splice variants. Hum Immunol 2002; 63: 317-323.

32. Awad MR, Webber S, Boyle G, Sturchioĉ C, Ahmed M, Martell $\mathrm{J}$, et al. The effect of cytokine gene polymorphisms on pediatric heart allograft outcome. J Heart Lung Transplant 2001; 20: $625-$ 630.

33. Holweg CT, Baan CC, Balk AH, Niesters HG, Maat AP, Mulder $\mathrm{PM}$, et al. The transforming growth factor-betal codon 10 gene polymorphism and accelerated graft vascular disease after clinical heart transplantation. Transplantation 2001; 71: 1463-1467.

34. Poole KL, Gibbs PJ, Evans PR, Sadek SA, Howell WM. Influence of patient and donor cytokine genotypes on renal allograft rejection: Evidence from a single centre study. Transpl Immunol 2001; 8: 259-265.

35. Marshall SE, McLaren AJ, McKinney EF, Bird TG, Haldar NA, Bunce $\mathrm{M}$, et al. Donor cytokine genotype influences the development of acute rejection after renal transplantation. Transplantation 2001; 71: 469-476

36. Sankaran D, Asderakis A, Ashraf S, Roberts IS, Short CD, Dyer PA, et al. Cytokine gene polymorphisms predict acute graft rejection following renal transplantation. Kidney Int 1999; 56: $281-288$.

37. Kobashigawa J, CrespoLeiro MG, Ensminger SM, Reichenspurner H, Angelini A, Berry G, et al. Report from a consensus conference on antibodymediated rejection in heart transplantation. J Heart Lung Transplant 2011; 30: 252-269.

38. Berry GJ, Burke MM, Andersen C, Bruneval P, Fedrigo M, Fishbein MC, et al. The 2013 International Society for Heart and Lung Transplantation Working Formulation for the standardization of nomenclature in the pathologic diagnosis of antibodymediated rejection in heart transplantation. J Heart Lung Transplant 2013; 32: 1147-1162.

39. Marshall SE, Welsh KI. The role of cytokine polymorphisms in rejection after solid organ transplantation. Genes Immun 2001; 2: 297-303.

40. Snapper CM, Finkelman FD, Paul WE. Differential regulation of IgG1 and IgE synthesis by interleukin 4. J Exp Med 1988; 167: $183-196$.

41. Mirel DB, Valdes AM, Lazzeroni LC, Reynolds RL, Erlich HA, Noble JA. Association of IL4R haplotypes with type 1 diabetes. Diabetes 2002; 51: 3336-3341

42. Choi WA, Kang MJ, Kim YJ, Seo JH, Kim HY, Kwon JW, et al. Gene-gene interactions between candidate gene polymorphisms are associated with total IgE levels in Korean children with asthma. $J$ Asthma 2012; 49: 243-252.

43. Mitsuyasu H, Izuhara K, Mao XQ, Gao PS, Arinobu Y, Enomoto T, et al. Ile 50Val variant of IL4RA $\alpha$ upregulates IgE synthesis and associates with atopic asthma. Nat Genet 1998; 19: $119-120$.

44. Ford AQ, Heller NM, Stephenson L, Boothby MR, Keegan AD An atopy-associated polymorphism in the ectodomain of the IL-4R(alpha) chain (V50) regulates the persistence of STAT6 phosphorylation. J Immunol 2009; 183: 1607-1616.

45. Knutsen AP, Vijay HM, Kariuki B, Santiago LA, Graff R, Wofford JD, et al. Association of IL-4RA single nucleotide polymorphisms, HLA-DR and HLA-DQ in children with Alternaria-sensitive moderate-severe asthma. Clin Mol Allergy 2010; 8: 5 .

46. Zhang R. Donor-specific antibodies in kidney transplant recipients. Clin J Am Soc Nephrol 2018; 13: 182-192.

47. Sharma S, Das M, Kumar A, Marwaha V, Shankar S, Singh P, et al. Purine biosynthetic pathway genes and methotrexate response in rheumatoid arthritis patients among north Indians. Pharmacogenet Genomics 2009; 19: 823-828.

48. Sauna ZE, Kimchi-Sarfaty C, Ambudkar SV, Gottesman MM Silent polymorphisms speak: How they affect pharmacogenomics and the treatment of cancer. Cancer Res 2007; 67: 9609-9612.

49. Whitmore KV, Gaspar HB. Adenosine deaminase deficiency: More than just an immunodeficiency. Front Immunol 2016; 7: 314.

50. Bottini N, De Luca D, Saccucci P, Fiumara A, Elia M, Porfirio $\mathrm{MC}$, et al. Autism: Evidence of association with adenosine deaminase genetic polymorphism. Neurogenetics 2001; 3: $111-$ 113.

51. Kim SH, Kim YK, Park HW, Kim SH, Kim SH, Ye YM, et al. Adenosine deaminase and adenosine receptor polymorphisms in aspirin-intolerant asthma. Respir Med 2009; 103: 356-363.

\section{Supplementary Files}

\section{Supplementary File 1}

Table S1. Analyzed genes involved in the complement system and B-cell biology

Table S2. Characterization of anti-HLA antibodies, immunosuppression regimen and AMR treatment

Table S3. Donor and donor-recipient SNP in genes involved in the complement system and B-cell biology

Please find supplementary file(s);

http://dx.doi.org/10.1253/circj.CJ-17-1320 